\title{
PRINCIPAL NEW ZEALAND EARTHQUAKES IN 1983:
}

\author{
Warwick D. Smith*
}

of the earthquakes which occurred during 1983, the most significant in engineering terms was without doubt that near Reporoa on December 15. Its magnitude was only 4.9, but its very shallow focus (probably only about $5 \mathrm{~km}$ ) meant that ground motions were strong, although not over a wide area. Reporoa suffered the most, but it was also felt strongly in Waimangu. Ground motion at places further away was apparently much more attenuated. The hotel tavern at Waimangu lost a lot of stock from shelves. Furniture there was overturned. In Reporoa a milk tank was twisted off its foundations at the Dairy Company, ridge tiles on a house were displaced, windows popped out of frames and some hot water cylinders were fractured. Switchgear tripped at some substations, causing power failures in certain areas. There were also some landslides in the Paeroa Range to the west of Reporoa, although the heavy rain there in the previous few weeks would have left the slopes unstable.

There were a few foreshocks and several days of aftershocks. The earthquake was not judged to warrant a major seismological field exercise, but one portable recorder from Rotorua was installed in the Waikite Valley. It recorded 150 small aftershocks on the first day, 70 the second day, and fewer thereafter.

In terms of inconvenience to the people who felt them, two swarms of earthquakes near Taupo must rate as significant events during 1983. Swarms are a common phenomenon, particularly in the central volcanic area of the North Island. Eiby (1966) documents a number which have occurred in New Zealand.

All have been located in areas of current or geologically recent volcaniam, although the relationship to that volcanism is not well understood. The phenomenon of a swarm is one where there is no clearly definable major event. This distinguishes it from the familiar pattern of a foreshock-mainshock-aftershock sequence.

From January 29 to the end of February, some 80 small shocks were reported felt, and other smaller ones were detected on instruments deployed for the purpose. Then in June there was another swarm, when more than 70 shocks were reported felt within ten days. None of these was large, the biggest reaching only magnitude 3.9 , but they were all very shallow (typically less than $5 \mathrm{~km}$ ) so they were felt sharpIy at intensities up to MM5.
The June swarm was also accompanied by fault movement, $4 \mathrm{~km}$ west of Taupo on the northern shore of the lake. The southeastern side of the Kaiapo Fault was upthrown $50 \mathrm{~mm}$, and there was $30 \mathrm{~mm}$ extension. The total length of the observed 1983 trace was $1200 \mathrm{~mm}$, comprising a set of "en echelon" tensional cracks $10 \mathrm{~m}$ in length (G.W. Grindley, pers. comm.)

None of the other earthquakes which occurred during the year was of any engineering significance. On January 26 a large shock of magnitude 7.3 occurred to the north of New Zealand, in the Kermadec Islands. It was felt, at low intensities, as far south as Christchurch. An earthquake of magnitude 4.6 on February 20, in Golden Bay, was felt throughout the Nelson area. On June 25 an earthquake of magnitude 5.2 occurred in Fiordiand, felt most strongly at Manapouri power station (MM5) and at lower intensities as far away as Cromwell.

of considerable scientific interest was the shock of magnitude 5.2 which occurred $550 \mathrm{~km}$ to the south-east of Dunedin on June 3 . This is a most unusual location, well away from the main axis of seismic activity which runs through the main islands of New Zealand. But such a location is not unknown. This shock was recorded by more than twenty seismographs within New zealand, and no doubt by more sensitive stations elsewhere, so it may be possible to do a special study of its mechanism.

\section{REFERENCE:}

Eiby, G.A. 1966: Earthquake swarms and volcanism in New Zealand. Bulletin Volcanologique XXIX, 61-74. 